\title{
Assessment of groundwater quality in eastern part of lower vellar basin, cuddalore district, tamilnadu, India
}

\author{
Dushiyanthan $\mathbf{C}^{1 *}$, Jeyavel Raja Kumar $\mathbf{T}^{1}$, Karthikeyan $\mathbf{K}^{2}$, Thiruneelakandan $\mathbf{B}^{1}$, \\ Davidraju ${ }^{3}{ }^{3}$, Suresh. $\mathbf{R}^{1}$ \\ ${ }^{I}$ Department of Earth Sciences, Annamalai University, Annamalai Nagar \\ ${ }^{2}$ Department of Civil Engineering, Annamalai University, Annamalai Nagar \\ ${ }^{3}$ Govt Engineering College, Tirunelveli \\ *Corresponding author E-mail: hydrodushi@gmail.com
}

\begin{abstract}
An attempt has been made in this present work to determine the groundwater quality in eastern parts of Lower vellar basin, Cuddalore district. Totally, ten groundwater samples were collected from bore well during premonsoon seasons and analyzed for physicochemical parameters to understand the hydro geochemistry of the water. The analysis results were interpreted with various geochemical diagrams such as Piper trilinear plot and USSL classification and Gibbs diagram. The range of chemical concentration of cations such as $\mathrm{Ca}$, $\mathrm{Mg}$, $\mathrm{Na}, \mathrm{k}$ and anions like $\mathrm{HCO} 3, \mathrm{Cl}$, and SO4 are 25.0 to $90.0 \mathrm{mg} / \mathrm{l}, 20.6$ to $117.5 \mathrm{mg} / \mathrm{l}, 11.9$ to $95.0 \mathrm{mg} / \mathrm{l}, 1$ to $130 \mathrm{mg} / \mathrm{l} \mathrm{and} 25$ to $197 \mathrm{mg} / \mathrm{l}$, 111.0 to $275.0 \mathrm{mg} / \mathrm{l}, 0.13$ to $0.78 \mathrm{mg} / \mathrm{l}$ respectively. To understand the geochemical facies interpreted with Piper Trilinear diagram and Gibb's dia-grams. The graphical interpretation of Piper trilinear diagram shows $\mathrm{Ca}$, $\mathrm{Na}$ facies followed by $\mathrm{Cl}$, $\mathrm{So} 4$, and $\mathrm{HCO} 3$ facies. Similarly, USSL and Gibb's diagrams represent C3S1 field and considerable number of samples in rock water interaction field. In the present study to under-stand groundwater quality of lower vellar basin.
\end{abstract}

Keywords: Groundwater, Hydro Geochemistry, Lowervellarbasin, Groundwater Quality, Hydrogeology, Premonsoon.

\section{Introduction}

Water is the prime natural resource for development of country depends on rapid development of increasing population and industrialization. Water is flowing in two forms namely, surface water and groundwater. Rapid urbanization, especially in developing countries like India, has affected the availability and quality of groundwater due to its overexploitation improper waste disposal, irrigational return water and lack of recharge. The Quality of groundwater is the function of its physical and chemical parameters which depend upon the soluble products of weathering, decomposition, and the related changes that occur with respect to time and space (Srinivasamoorthy 2011). The chemical composition of groundwater plays a significant role in determining the water quality for various utility purposes like domestic, agricultur$\mathrm{al}$, and industrial purposes. Criteria used for classification of water for particular purpose is not suitable for other standards; better results can be obtained by combining chemistry of all the ions than the individual or paired ionic character (Hem 1985). Besides, the limited available quantity of potable water due to salinity and pollution generated by sea water intrusion, agricultural activities and its environs is at the verge of reaching an alarming situation (Mala 1997). The present studies focus on the quality of groundwater eastern parts of Lower vellar basin, Chidambaram taluk. This study was mainly on the chemical nature of the groundwater in this region thereby management of the resources can take these factors in consideration for determining the sustainable usage of this essential commodity.

\section{Study area}

The study area Eastern part of lower vellar basin in Chidambaram taluk and falls in in the survey of India top sheet number 58N/11 lies the latitude 11 o $39^{\prime}$ 'to 11 o $24^{\prime}$ ' and longitude $79 \mathrm{o} 30^{\prime}$ to $79 \mathrm{o}$ 48' shown in Fig.1. Geologically, the study area is a sedimentary terrain and the eastern parts are covered by the quaternary unconsolidated formations of clay, black clay, alluvium, silts, kankar and lateritic of recent to sub recent age and the western parts by the tertiary formations of Mio-Pliocene age represented by litho units - sand stones, grits, clays with lignite seams and pebble beds shown in Fig.2. Geomorphologically, the area is covered by flood plain along the river course and remaining area by alluvial plain and coastal plain. The normal rainfall of the district $373.3 \mathrm{~mm}$. The higher rates of relative humidity (about $85 \%$ ) is observed during the north east monsoon period and in summer the relative humidity is low, about $60 \%$.

\section{Methodology}

In the present study 10 groundwater samples have been collected from bore wells during pre-monsoon shown in Fig.3. The samples were collected in clean polythene bottles prescribed by (APHA 1998). The analysis has been carried out for various physicchemical parameters, PHS was measured portable $\mathrm{pH}$ meter, and EC were measured Electrode, then TDS were dune by calculation method. With respect to cation, calcium, magnesium was analyzed volumetric method and sodium, potassium were analyzed by 
Flame photometer, with respect to anions Chloride and Bicarbonate were done by volumetric method, Sulphate were analysed by Spectrophotometer. The analysed data interpreted using WATCLAST software (Chidambaram et al. 2004). The groundwater sample analysis results shows in table-1.

\section{Results and discussion}

\subsection{Potential hydrogen $(\mathrm{pH})$}

The $\mathrm{pH}$ of water is an important indication of its quality and provides important information of geochemical equilibrium or solubility calculation (Hem 1985). The $\mathrm{pH}$ of groundwater in the study area varied from 7.3 to 9.4 , this indicating study area, some well water having higher concentration of $\mathrm{pH}$ due to weathering of plagioclase feldspar by dissolved atmospheric carbon dioxide that will release sodium and calcium which progressively increase the $\mathrm{pH}$ and alkalinity. The values for all the samples are within the limits specified as 6.5 to 8.5 (WHO 1993).

\subsection{Electrical conductivity}

Electrical conductivity of the groundwater is varying from 562 to $6662 \mathrm{micromhos} / \mathrm{cm}$. The maximum limit of EC in drinking water is prescribed as 1500 microsimns/cm (WHO 1993). The conductivity measurement provides an indication of ionic concentrations. It depends upon temperature, concentration and types of ions present (Hem 1985). The high conduction was observed in 2 ground water sample location which may attribute to high chloride concentration in ground water (Davis and Dewist 1996). The classification proposed by (Wilcox 1955).

\begin{tabular}{lll}
\hline Classification & Values Range $(\mathrm{ppm})$ & No. of samples \\
\hline Excellent & Less than 250 & Nil \\
Good & $250-750$ & 1 \\
Permissible & $750-2250$ & 7 \\
Doubtful & $2250-5000$ & 1 \\
Unsuitable & Greater than 5000 & 1 \\
\hline
\end{tabular}

\subsection{Total dissolved solids}

The principal ions contributing to TDS are bicarbonate, carbonate, chloride, sulphate, nitrate, sodium, potassium, calcium and magnesium (EPA 1976). The TDS of ground water varies from 224.2 to $3090.6 \mathrm{mg} / \mathrm{l}$. The groundwater samples have been classified based on the concentration of TDS (USSL 1954).

\begin{tabular}{lll}
\hline Classification & Values Range $(\mathrm{ppm})$ & No. of samples \\
\hline Desirable & Less than 200 & Nil \\
Permissible & $200-500$ & 3 \\
Useful & $500-1500$ & 6 \\
Unfit & $1500-3000$ & 1 \\
\hline
\end{tabular}

\section{Cations}

The major cation concentrations $(\mathrm{Ca}+, \mathrm{Mg}+, \mathrm{Na}+, \mathrm{K})$ in the groundwater are below the WHO standards 1993. Calcium and magnesium ions present in ground water is particularly derived from leaching Of limestone, dolomites, gypsum and anhydrites Whereas the calcium ions is also derived from Cation exchange process (Garrels 1976). The concentration of $\mathrm{Ca}$ is varied from $25.0 \mathrm{mg} / \mathrm{l}$ to $90.0 \mathrm{mg} / \mathrm{l}$. The limit of Ca for drinking water is specified as $100 \mathrm{mg} / \mathrm{l}$ (WHO 1993). The Magnesium concentration is varied from $20.6 \mathrm{mg} / \mathrm{l}$ to $117.5 \mathrm{mg} / \mathrm{l}$. The limit of $\mathrm{Mg}$ for drinking water is $30 \mathrm{mg} / \mathrm{l}$ (WHO 1993). Similarly, the Sodium concentration is varying from $11.9 \mathrm{mg} / \mathrm{l}$ to $95.0 \mathrm{mg} / \mathrm{l}$. The limit for drinking water is specified as $175 \mathrm{mg} / \mathrm{l}$ (WHO 1993). The Potassium concentration is varied from $1.0 \mathrm{mg} / \mathrm{l}$ to $130.0 \mathrm{mg} / \mathrm{l}$. The limit of $\mathrm{K}$ for drinking water is specified as $25 \mathrm{mg} / \mathrm{l}$ (WHO 1993).

\section{Anions}

The major anion like $\mathrm{Cl}$ concentration is varied from $111.0 \mathrm{mg} / \mathrm{l}$ to $275.0 \mathrm{mg} / \mathrm{l}$. The limit of chloride concentration for drinking water is specified as $600 \mathrm{mg} / \mathrm{l}$ (WHO 1993). The bicarbonate presence varied from $25 \mathrm{mg} / \mathrm{l}$ to $197.0 \mathrm{mg} / \mathrm{l}$. The Sulphate concentration is varied from $0.13 \mathrm{mg} / \mathrm{l}$ to $0.78 \mathrm{mg} / \mathrm{l}$. The limit of sulphate for drinking water is specified as $250 \mathrm{mg} / \mathrm{l}$ (WHO 1993). All the sample locations are within the limit in the study area. A part from the natural rock sources, sulphates could be introduced through the application of sulphatic soil conditioners (Karanth 1987).

\section{Hydro geochemical Facies}

The concentrations of major ionic constituents of groundwater samples were plotted in the Piper trilinear diagram to determine the water type. The classification for cation and anion facies, in terms of major ion percentages and water types, is according to the domain in which they occur on the diagram segments (Piper 1953).The Piper trilinear diagrams are very useful to bringing out the chemical relationships among ground waters in more definite terms (Walton 1970). Hence, the present study area ground water samples have been plotted $\mathrm{Ca}+\mathrm{Na}$ and $\mathrm{Cl}+\mathrm{So} 4+\mathrm{HCO} 3$ facies Fig.4.

\section{USSL classification}

The USSL Diagram has been used to understand the alkali hazard of the groundwater samples for the study area, because this interpretation is very much useful for judging the quality of groundwater for the use of agricultural purpose (Todd 1980). Where the sodium adsorption ratio is plotted against specific conductance. The sixteen classes in the diagram indicate the extent that waters can affect the soil in terms of salinity hazard as low(C1),Medium(C2), high(C3), and very high(C4)and similarly sodium hazard as $\operatorname{low}(\mathrm{S} 1)$, medium(S2), $\operatorname{High}(\mathrm{S} 3)$ and very high(S4). The analytical data plotted most of the sample C3S1.This category is predominant in the study area and it is suitable for irrigations purposes shown in Fig. 5.

\section{Sodium Absorption Ratio (SAR)}

Sodium concentration in ground water is important since increase of sodium concentration in water effect deterioration of the soil properties reducing permeability (Kelley 1951). The relative activity of sodium ion in the exchange reaction with soil is expressed in terms of a ratio known as sodium adsorption ratio. It is an important parameter for determining the suitability of irrigation water, because it is a measure of alkali sodium hazard for crops (Richards 1954). Classified ranges of SAR values of the study area have been classified as follow.

\begin{tabular}{lll}
\hline Classification & Value Range $(\mathrm{epm})$ & No. of Sample \\
\hline Excellent & Less than 10 & 9 \\
Good & $10-18$ & Nil \\
Fair & $18-26$ & 1 \\
Poor & Greater than 26 & Nil \\
\hline
\end{tabular}

\section{Gibb's Diagram}

The mechanism controlling chemical relationships of groundwater based on aquifer Lithology and nature of geochemical reactions and solubility of interaction rocks has been studied following Gibbs (1970), Viswanathaiah et al. (1978). According to the variation in the ratio of $\mathrm{Na}+\mathrm{K} / \mathrm{Na}+\mathrm{K}+\mathrm{Ca}$ and $\mathrm{Cl} / \mathrm{Cl}+\mathrm{HCO} 3$ as a function of TDS Fig 6. From These Gibbs plot, it could be confirm that the chief mechanism controlling the chemistry of ground water interaction of the study area dominated by rock water interaction and some location fall in evaporation zone 
Table 1: Hydro geochemical analysis data of the study area.

\begin{tabular}{|c|c|c|c|c|c|c|c|c|c|c|c|}
\hline S.no & Location & $\mathrm{Ca}$ & $\mathrm{Mg}$ & $\mathrm{Na}$ & $\mathrm{K}$ & $\mathrm{Cl}$ & $\mathrm{HCO} 3$ & $\mathrm{SO} 4$ & $\mathrm{pH}$ & Ec & TDS \\
\hline 1 & Tachakkadu & 35 & 47.9 & 42 & 11 & 163 & 109 & 0.34 & 8.5 & 1577 & 250.1 \\
\hline 2 & Ariyakoshti & 45.2 & 35.9 & 80 & 25 & 138 & 165 & 0.78 & 7.79 & 6662 & 3090.6 \\
\hline 3 & periyapattu & 90 & 81.5 & 36 & 1 & 125 & 112 & 0.38 & 8.14 & 1255 & 587.1 \\
\hline 4 & Villiyanallur & 31 & 55.1 & 59 & 45 & 231 & 107 & 0.54 & 8.5 & 2275 & 1005.6 \\
\hline 5 & Sirupalaiyur & 55 & 47.3 & 11.9 & 6 & 163 & 142 & 0.78 & 7.3 & 1715 & 2275.2 \\
\hline 6 & Mutlur.c & 68 & 20.6 & 49.6 & 16.3 & 197 & 25 & 0.13 & 7.5 & 1255 & 492.8 \\
\hline 7 & Maduvankarai & 39 & 117.5 & 40 & 21 & 275 & 127 & 0.28 & 7.43 & 1280 & 1270.2 \\
\hline 8 & Puvanikuppam & 43.2 & 42.7 & 29 & 52 & 153 & 117 & 0.3 & 8.0 & 562 & 229.2 \\
\hline 9 & Adinarayanapuram & 25 & 43.1 & 35 & 3 & 111 & 197 & 0.58 & 7.58 & 1014 & 554.5 \\
\hline 10 & Manambadi & 45 & 36.6 & 95 & 130 & 149 & 120 & 0.34 & 7.32 & 1240 & 680.8 \\
\hline
\end{tabular}

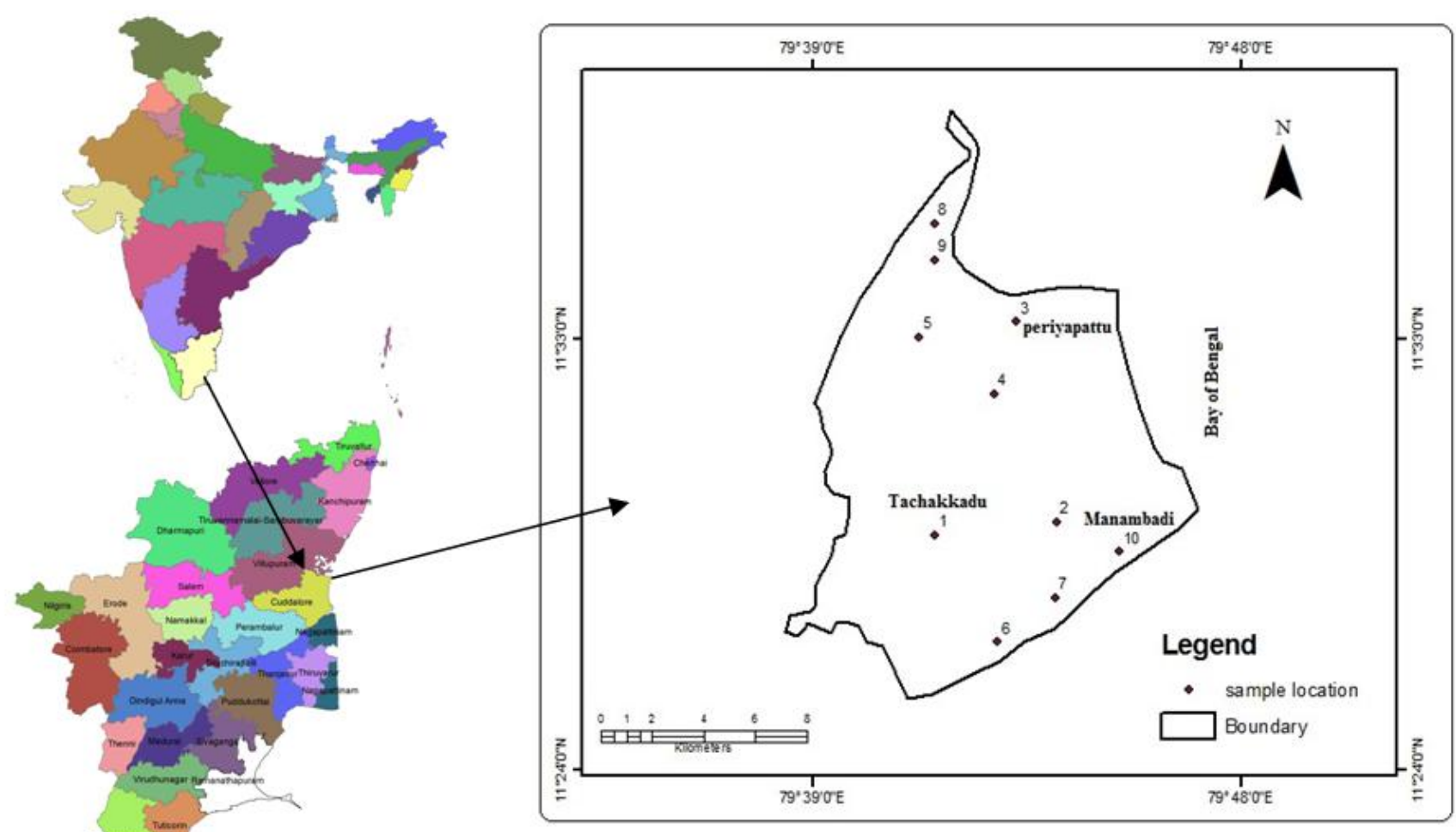

Fig. 1: Study area.

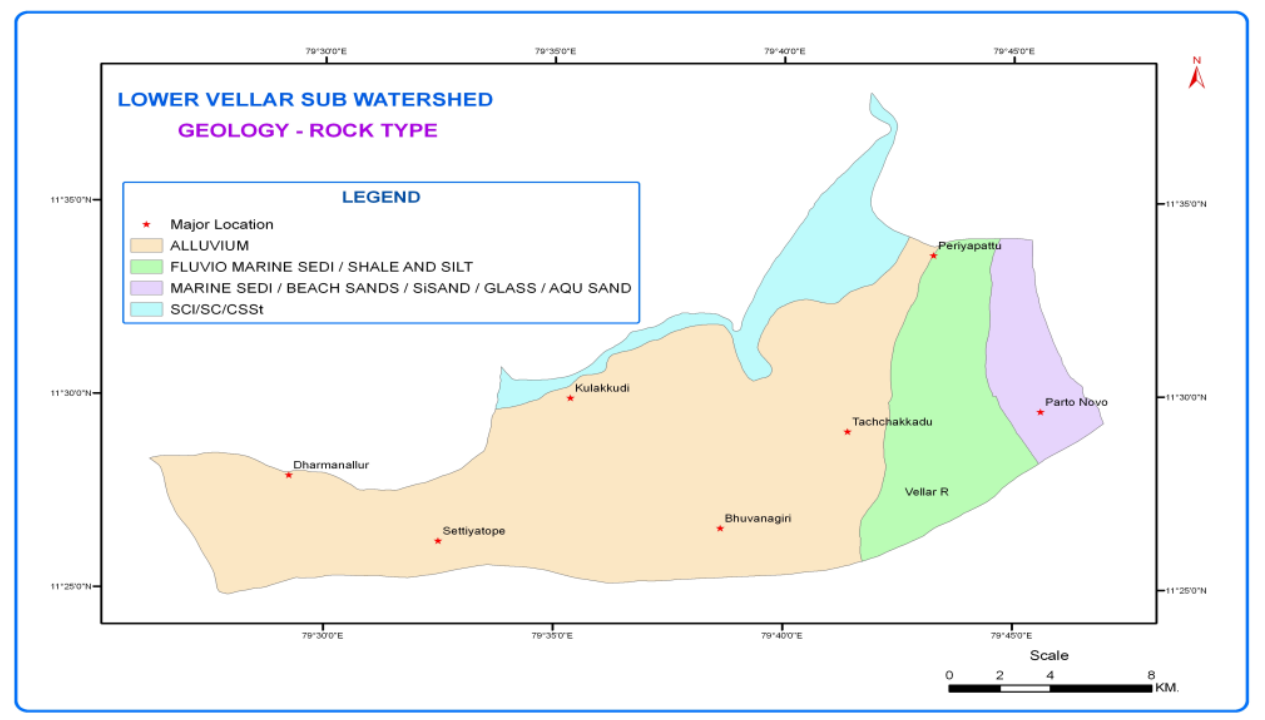

Fig. 2: Geology map of the study area. 


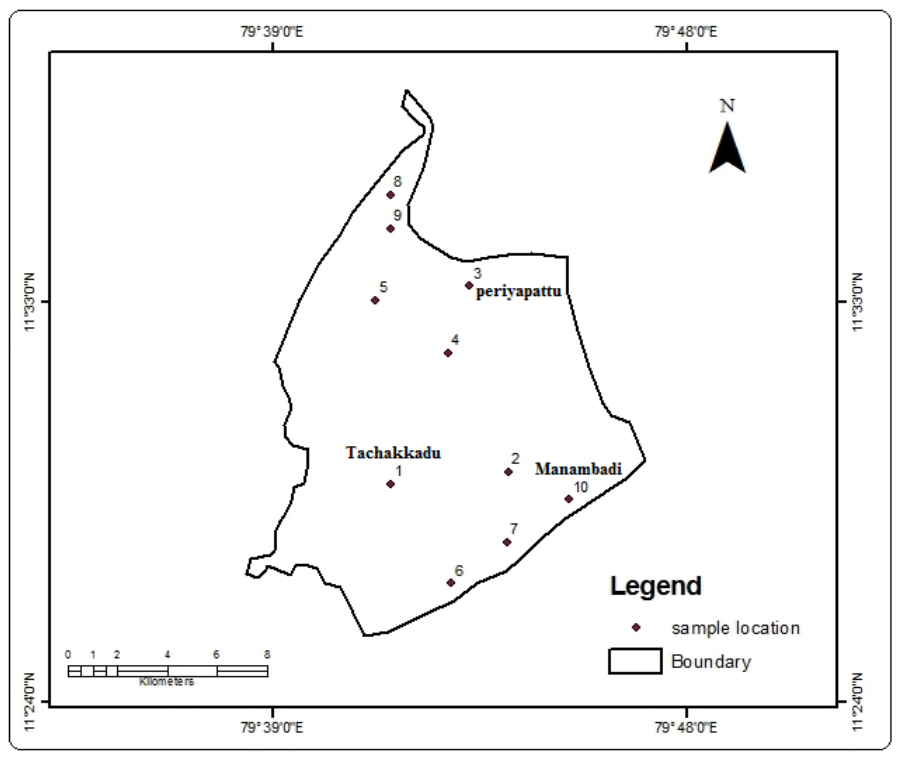

Fig. 3: Water sample location map.

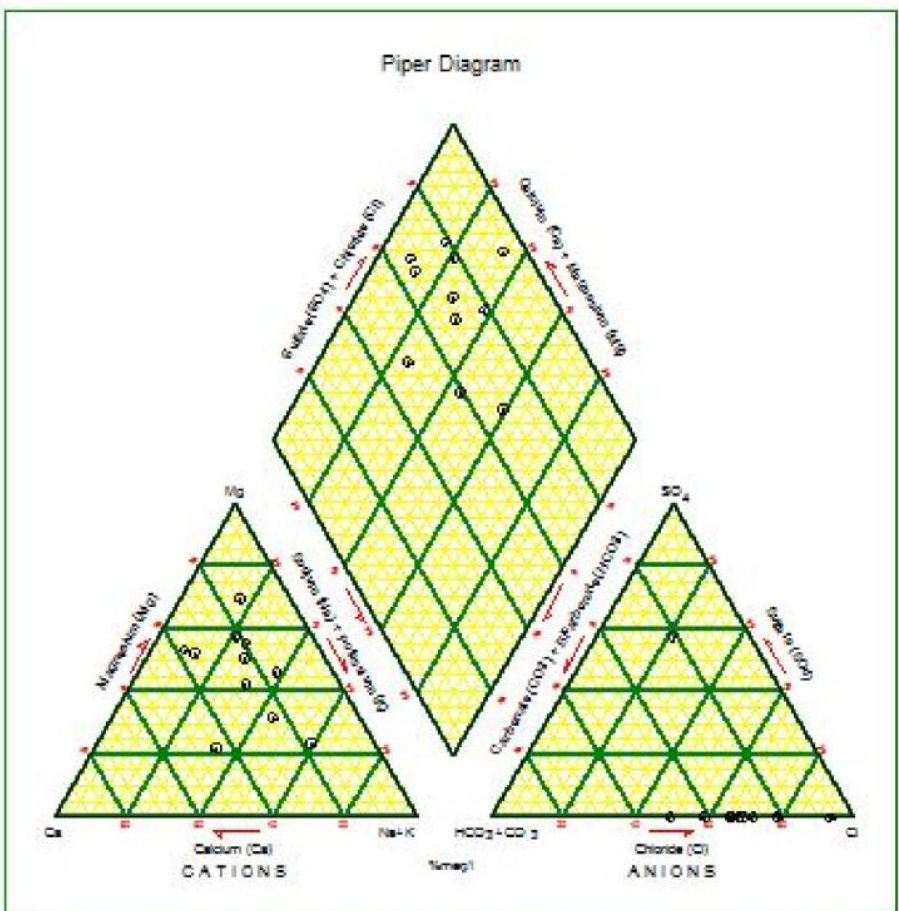

Fig. 4: Piper trilinear diagram.

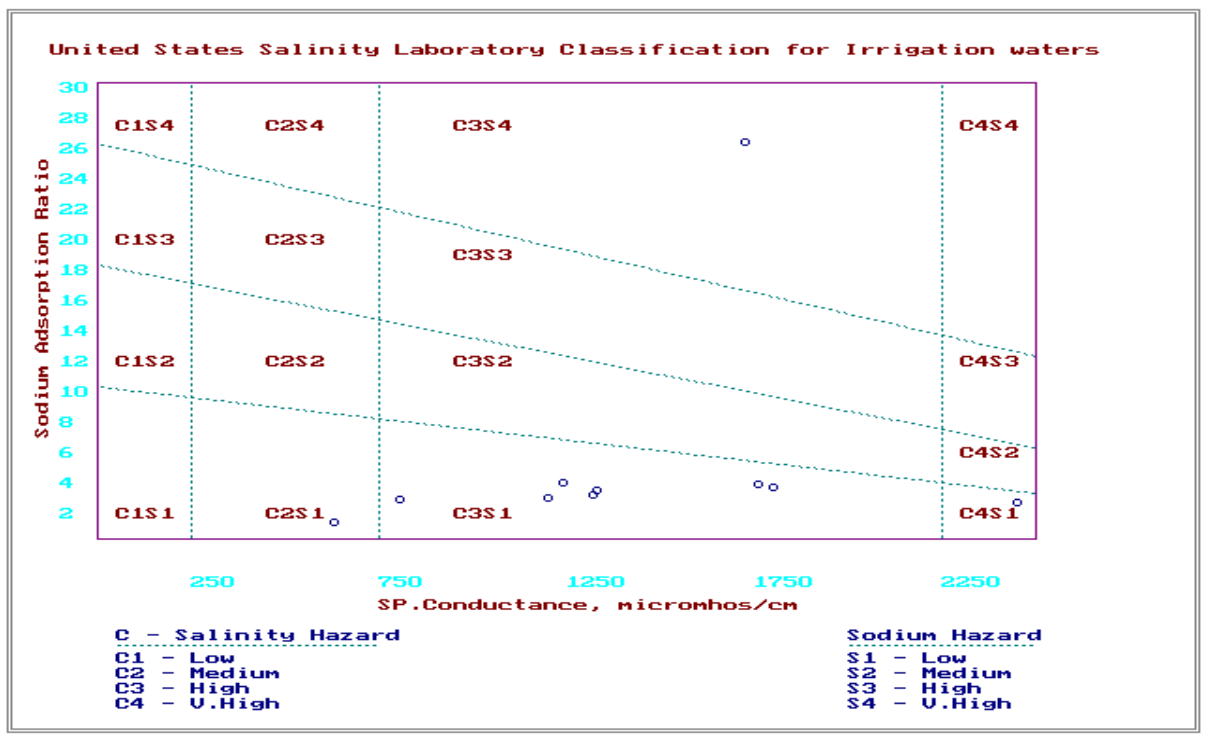

Fig. 5: USSL classification. 


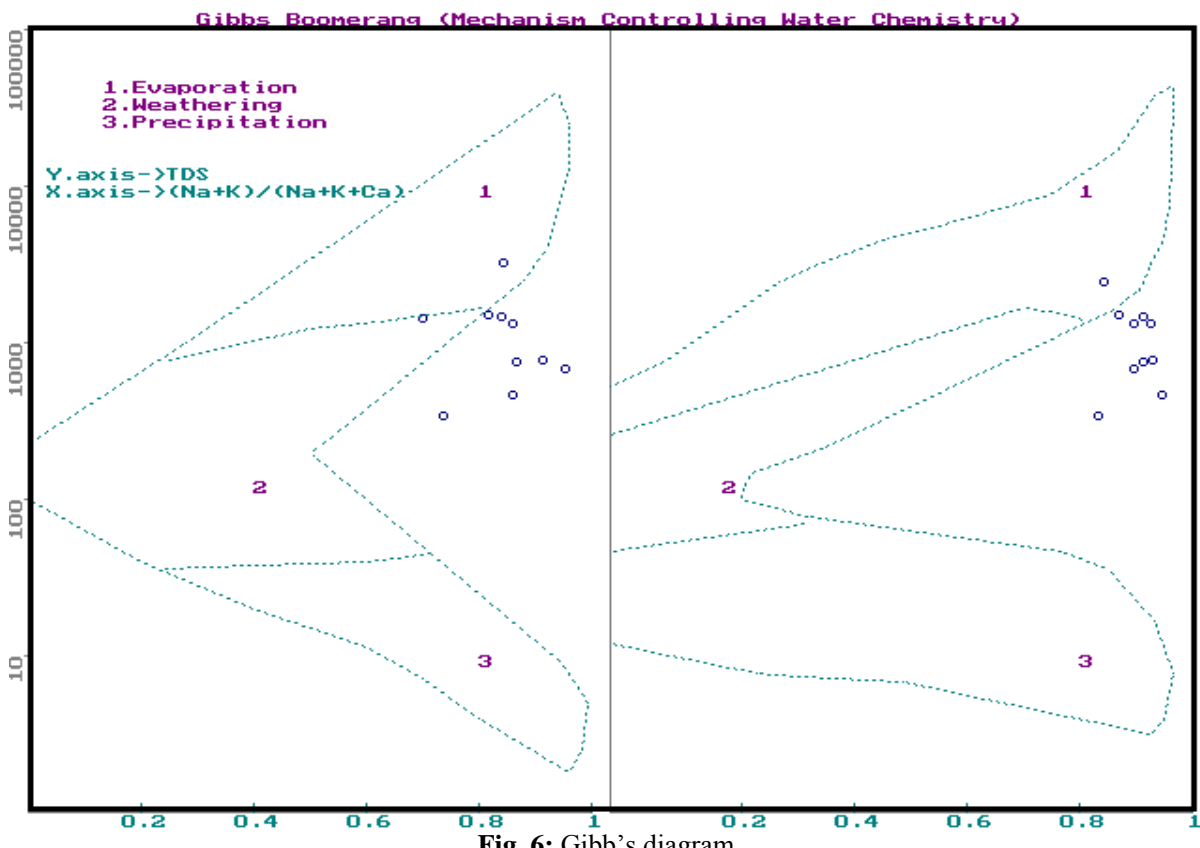

Fig. 6: Gibb's diagram.

\section{Conclusion}

From the hydrogeochemical study of the groundwater sample along the eastern parts of lower Vellar basin, it is observed that the most of the groundwater sample not exceeding the maximum permissible limit in their quality. The chemical relationship witnessed the water facies of $\mathrm{Ca}+\mathrm{Na}$ and $\mathrm{Cl}+\mathrm{So} 4+\mathrm{HCO} 3$. It is possible ionic base reaction between $\mathrm{Ca}$ and $\mathrm{Na}$ from the study area The USSL interpretation helped to understand the soil suitability for cultivation of crops. It indicate that High salinity and Low sodium hazard within the permissible limit and hence the water is not harmful to the soil and not affected the yield crop.

The Gibb's diagrams too strongly favour the concentration of ions from rock water interaction. Hence the present amount of ionic concentration mainly from the subsurface formation such as clay, sandy clay, sand, shale by realising element into the groundwater. Thus, the study helps us to understand the hydrogeochemical characters and to determine the sources of dissolved ionic constitution in the eastern parts of lower Vellar basin.

\section{References}

[1] APHA (1998) Standard methods for the examination of water and waste water. American public health association, Washington.

[2] Chidambaram S, Ramanathan AL, Srinivasamoorthy K and Ananthan P (2004) WATCLAST - A computer program for hydrogeochemical studies, Recent trends in hydrogeochemistry (case studies from surface and subsurface waters of selected countries), Published by Capital publishing company, New Delhi, pp.203- 207.

[3] Davies SN and De Wiest RJM (1996) Hydrogeology, John Welly and Sons, Inc, New York.

[4] Environmental Protection Agency (EPA) (1976) Quality Criteria for Water, Washington D.C, USA.

[5] arrels RM (1976) A Survey of Low Temperature Water Mineral Relations, in Interpretation of Environmental Isotope and Hydro geochemical Data in Groundwater Hydrology: Vienna, International Atomic Energy Agency, 65-84.

[6] Gibbs RJ (1970) Mechanism controlling World's water chemistry, Science, 170, pp 1088- 1090 .

[7] em JD (1985) Study and interpretation of the chemical characteristics of natural water. USGS Water Supply Paper, 2254, 117-120.

[8] aranth KR (1987) Ground water Assessment, Development and Management, Tata Mc Graw Hills Publications Company Limited, New Delhi.
[9] Kelley WP (1951) Alkali soils-their formation properties and reclamation. Reinold Publ. Corp., New York.

[10]Mala V (1997) Study of the environmental hydrogeochemical and sedimentological aspects between Puduchatram to Chidambaram area, Cuddalore district, East coast of India, M.Phil dissertation, Annamalai University, p146.

[11]Piper AM (1953) A graphic procedure in the geochemical interpretation of water analyses. Trans. U.S. Geol. Surv. Groundwater Notes 12.

[12]Richards LA (1954) Diagnosis and improvement of Agriculture Handbook, Saline and alkali soil, U.S. Department of Agriculture, pp. 60

[13] Srinivasamoorthy $K$, Nanthakumar C, Vasanthavigar $M$, Vijayaraghavan K, Rajivgandhi R \& Chidambaram S, Anandhan P, Manivannan R, Vasudevan S (2011) Groundwater quality assessment from a hard rock terrain, Salem district of Tamilnadu, India Arab J Geosci, 4, 91-102.

[14]Todd DK (1980) Groundwater Hydrology, 2nd Edn.John Wiley and Sons, New York, p535. U.S.Salinity Laboratory (1954) Diagenesis and Improvement of saline and alkali soils,U.S.Dept.Agriculture Hand book-60,Washington,D.C.,p160.

[15] Viswanathaiah MN, Sastri JCV and Rame Gowda B (1978) Mechanisms controlling the chemistry of groundwater of Karnataka. Indian Mineralogist. 19, 65-69.

[16]Walton WC (1970) Groundwater resource evaluation. McGraw Hill Book Co., New York, p664.

[17]WHO (1993) Guidelines for drinking- water quality, v.1. Recommendations, Geneva: WHO. Pp. 1-4.Wilcox LV (1955) Classification and use of irrigation water, U.S. Dept. of Agriculture, Circular969. 